\title{
Correlational Study Between Capital Markets and Financial Performance of Commercial Banks in Rwanda
}

\author{
Mbonigaba Celestin \\ Business and Development Studies, Kibogora Polytechnic, Nyamasheke, Rwanda
}

Email address:

mboncele5@gmail.com

\section{To cite this article:}

Mbonigaba Celestin. Correlational Study Between Capital Markets and Financial Performance of Commercial Banks in Rwanda. International Journal of Accounting, Finance and Risk Management. Vol. 4, No. 3, 2019, pp. 95-101. doi: 10.11648/j.ijafrm.20190403.13

Received: July 13, 2019; Accepted: August 5, 2019; Published: August 29, 2019

\begin{abstract}
The main objectives of this study were to examine the link between Capital Markets and the Financial Performance of Commercial Bank. The study was guided by three objectives such as: To examine the effect of equity market on the financial performance, to assess the effect of bond market on the financial performance, to establish the effect of securitized products on the financial performance of Bank of Kigali. The study adopted quantitative approach to collect data from 32 respondents' employees of BK by using purposive sampling technique. Data collected was analyzed using SPSS, and the instruments of data collection were questionnaire, interview, and documentary techniques. The results show that perceptions of respondents about effect of bond market on the financial performance of Bank of Kigali Rwanda show that more than $84.4 \%$ of respondents confirmed that Size of Equity market affects market capitalization for generating net profit margin for BK; and $84.4 \%$ that size dimension of equity market reflects turnover ratio of BK. The R-Square was.759 while ANOVA shows the Sum of Squares of 7.875. The results on the effect of bond market on the financial performance of Bank of Kigali confirmed by $84.4 \%$ of respondents who said that Bond market of BK helps to increase its interest income; and $78.1 \%$ of respondents confirmed that accessibility of Bond market facilitates an increase of capital gain to BK in Rwanda. R-Square was.610 and ANOVA table shows that Sum of Squares of 7.875. The effect of securitized products on the financial performance of Bank of Kigali confirmed by more than $84.4 \%$ who said that commercial mortgages offered by BK increases the internal return of this commercial bank; $78.1 \%$ of respondents participated in the study confirmed credit card receivables facilities BK to increase income from borrowers of this bank; and 68.8\% agreed that the Auto loans and student loans of BK increase the net profit margin. R-Square was 743 and its adjusted R-Square was.638. ANOVA table shows that Sum of Squares was 7.875 combining the regression of 5.850; and residual of 2.025. Mean Square was.650 for regression while.092 was on the side of residual in the Mean Square. As conclusion, based to the findings, there is significant positive effect of Capital Market son the financial performance of Bank of Kigali in Rwanda.
\end{abstract}

Keywords: Capital Market, Financial Performance, Commercial Banks

\section{Introduction}

This study is based on locally owned public commercial public bank in Bank. The researcher selected this sample due to the fact that there are only locally owned private commercial banks in Rwanda. In addition to that it is the largest private owned commercial banks in Rwanda. The study is carried in the financial sector especially in Bank of Kigali Rwanda limited [9]. The financial sector plays an essential role in providing and channeling financing for investment. Beyond providing short-term finance for businesses' day-to-day operations and other temporary cash requirements, financial institutions, Capital Markets and institutional investors are also sources of long-term finance that is finance which is available for an extended period of time [11]. The importance of long-term finance lies in its pivotal role in satisfying long-term physical investment needs across all sectors in the economy and specifically in key drivers of growth, competitiveness and employment such as the infrastructure, real estate, $R \& D$ and new ventures [2].

According to WB, Banking institutions play an important role in the economic life of any country with the result that continued strength, stability and soundness of the entire banking system is a matter of public concern. Banking institutions act as the 
principal depository for public funds [14]. The safety and ready availability of these funds for transactions and other purposes is essential to the stability and efficiency of the financial system [6]. Banks also employ these funds to make loans and investments in addition to being the main vehicle through which monetary policy is implemented. This study was guided by three theories such as the Modigliani Miller Theorem; Pecking Order theory; and agency cost theory.

\section{Statement of the Problem}

Various private locally owned banks in Rwanda have been taken over by various foreign banks. A case in point, Agaseke bank was taken over by Bank of Africa 2016, Bank Popularize merged with Atlas Mara in 2016. The report by National Bank of Rwanda (NBR) (2016) revealed that most local banks lack enough liquidity to pay financial obligations to compete with the foreign banks. The report further revealed that most banks are facing a liquidity problem [4].

Bank of Kigali (BK) is committed to transforming the lives of Rwandans not only through providing the most innovative financial solutions on the market but also by giving back to the community, where net profit ratio in 2012 which is $33.89 \% \%$; in 2013 net profit increased on $33.13 \% \%$; in 2014 , NP was $36.17 \%$; in 2015 , NP was $36.46 \% .2016$, NPM was $34.46 \%$; and in 2017, NPM was $31.29 \%$ [7].

However, it is within this context that the researcher wants to assess how Capital Markets contributes to the financial performance of commercial banks in Rwanda.

\section{Objectives of the Study}

i. To examine the effect of equity market on the financial performance of Bank of Kigali

ii. To assess the effect of bond market on the financial performance of Bank of Kigali

iii. To establish the effect of securitized products on the financial performance of Bank of Kigali

\section{Literature Review}

Tumukunde, (2015) studied the Capital Markets and financial performance of financial institutions in Rwanda. The objectives of the study were to identify various financial instruments used by Rwanda Stock Exchange on Rwandan Market place, to identify the indicators of financial sector development of Rwanda on basis of Capital Markets and to find out the contribution of Capital Markets of Rwanda Stock Exchange to the financial economic development of financial sector in Rwanda. Methodology used was based on the techniques and methods that are used to collect and analyze data from RSE.

The findings showed that financial instruments introduced by Rwanda Stock Exchange were Stock Market at 5\%; Bond Market at 16\%; Money Market at 23\%; Cash or Spot Market at 21\%; Derivative Market at 15\%; Forex and the Interbank Market were on $15 \%$ while Rights and Warrants at 5\%. Much as these instruments were identified, Tumukunde did not show the extent to which these affected commercial banking operation.

Karemera (2013) studied the relationship between regulation of Capital Markets and financial performance of Rwanda commercial banks. The objective of this study was to establish the relationship between Regulation and Financial Performance of commercial banks in Rwanda. The study had three specific objectives; establishing how capital requirement ratio, liquidity ratio and management efficiency ratio affect financial performance of commercial banks in Rwanda. The findings of the study in some areas concur with past studies while in others it contradicts past findings by other scholars. The overall finding and conclusion of the study was that all the measures of regulation used in this study are not significant predictors of financial performance of commercial banks in Rwanda. These findings explored regulation prospects but not the effects of Capital Markets operations on commercial banking in Rwanda.

\section{Research Methodology}

This study adopted descriptive cross sectional survey design. The target population in this study was the employees of Bank of Kigali with 40 employees were targeted from the head office in different department. The purposive sampling technique was used to select 32 of respondents. The information used in this research was originated from primary and secondary source while data collection techniques were questionnaire and documentary techniques. Data were analyzed using both quantitative and qualitative technique and the results were presented by using the descriptive methods of data analysis.

\section{Data Analysis and Discussion}

The questionnaire was distributed to 32 respondents' employees of BK and they have been given one week and two days of responding the questions where the researcher found the participation rate of $100.0 \%$ of respondents. This section illustrates summary of main findings in relation with the effect of equity market on the financial performance of Bank of Kigali; the effect of bond market on the financial performance of Bank of Kigali; and the effect of securitized products on the financial performance of Bank of Kigali.

\subsection{Effect of Equity Market on the Financial Performance of Bank of Kigali}

Table 1. Effect of equity market on the financial performance of Bank of Kigali.

\begin{tabular}{llll}
\hline & Mean & Std. Deviation & Comments \\
\hline Overall Assessment & 1.85069 & 1.0555 & Strong heterogeneity \\
\hline
\end{tabular}

Source: Primary data, (2018). 
Table 1 describes the effect of equity market on the financial performance of Bank of Kigali. Overall assessment shows that equity market affects the financial performance of Bank of Kigali; this was indicated by a mean of 1.85069 and a standard deviation of 1.0555 . This implies that there is an effect of equity market on the financial performance of Bank of Kigali.

Table 2. Model Summary.

\begin{tabular}{lllll}
\hline Model & R & R Square & Adjusted R Square & Std. Error of the Estimate \\
\hline 1 & $871^{\mathrm{a}}$ & 759 & 660 & 29382 \\
\hline
\end{tabular}

It was found that model summary table 2 shows the RSquare of.759 with Adjusted R-Square of.660 which shows that there is significant effect of equity market on the financial performance of Bank of Kigali.
The findings on ANOVA table show that Sum of Squares was 7.875 included by regression of 5.976 and residual of 1.899. Mean Square was also.664 for regression while on residual, the Mean Square was.086.

\subsection{Effect of Bond Market on the Financial Performance of Bank of Kigali}

Table 3. ANOVAa.

\begin{tabular}{lllllll}
\hline Model & & Sum of Squares & Df & Mean Square & F & Sig. \\
\hline \multirow{2}{*}{1} & Regression & 5.976 & 9 & 664 & $000 \mathrm{~b}$ \\
& Residual & 1.899 & 22 & 086 & \\
& Total & 7.875 & 31 & & \\
\hline
\end{tabular}

Table 4. Effect of bond market on the financial performance of Bank of Kigali.

\begin{tabular}{llll}
\hline & Mean & Std. Deviation & Comments \\
\hline Overall Assessment & 1.86066 & 0.974222 & Strong heterogeneity \\
\hline
\end{tabular}

Source: Primary data, (2018).

Table 4 describes the Effect of bond market on the financial performance of Bank of Kigali. Overall assessment shows that bond market affects the financial performance of Bank of Kigali; this was indicated by a mean of 1.86066 and a standard deviation of 0.974222 . This implies that there is an effect of bond market on the financial performance of Bank of Kigali

Table 5. Model Summary.

\begin{tabular}{llll}
\hline Model & R & R Square & Adjusted R Square \\
\hline 1 & $781^{\mathrm{a}}$ & 610 & 450 \\
\hline
\end{tabular}

The model summary table shows that the R-Square was.610 and its adjusted R-Square was.450. This result helps us to confirm there is significant effect of bond market on the financial performance of Bank of Kigali.

Table 6. $A N O V A^{a}$.

\begin{tabular}{lllllll}
\hline Model & & Sum of Squares & Df & Mean Square & F & Sig. \\
\hline 1 & Regression & 4.802 & 9 & 534 & $005^{\mathrm{b}}$ \\
& Residual & 3.073 & 22 & 140 & \\
& Total & 7.875 & 31 & & \\
\hline
\end{tabular}

Dependent Variable: Financial Performance.

The findings on ANOVA table show that Sum of Squares was 7.875 that included by regression of 4.802 and residual of 3.073. Mean Square was also .534 for regression while on residual, the Mean Square was .140.

\subsection{Effect of Securitized Products on the Financial Performance of Bank of Kigali}

Table 7. Effect of securitized products on the financial performance of Bank of Kigali.

\begin{tabular}{llll}
\hline & Mean & Std. Deviation & Comments \\
\hline Overall Assessment & 1.978777 & 1.106222 & Strong heterogeneity \\
\hline
\end{tabular}

Source: Primary data, (2018).

Table 7 describes the securitized products influences the financial performance of Bank of Kigali. Overall assessment shows that securitized products influence the financial performance of Bank of Kigali.; this was indicated by a mean of 1.978777 , and a standard deviation of 1.106222. This implies that there is significant effect of securitized products 
on the financial performance of Bank of Kigali.

\subsection{Linear Regression Analysis}

A linear regression line is used as an equation of the form $Y=a+b X$, where $X$ is the explanatory variable and $Y$ is the dependent variable. The slope of the line is $b$, and $a$ is the intercept (the value of $y$ when $x=0$ ). The study uses linear regression by analyzing the Capital Markets in terms of "Bond market; Securitized products; and Equity market investment" as independent variable, with financial performance in terms of "profitability; liquidity, and Capital adequacy" as dependent variable. The study used the formula of $Y=\beta_{0}+\beta_{1} X_{1}+\beta_{2} X_{2}+\beta_{3} X_{3+} \varepsilon$.

$Y$ is dependent variable indicator which is "financial performance's is independent variable factors which are "Bonds market; Securitized products; and Equity market investment".

\subsubsection{Capital Markets and Profitability of Bank of Kigali Rwanda}

This section shows the influences of Capital Markets to the profitability of Bank of Kigali Rwanda as table 8 indicated as follows.

Table 8. Linear Regression Test of Capital Markets factors on the profitability of BK Rwanda.

\begin{tabular}{|c|c|c|c|c|c|c|}
\hline \multirow{2}{*}{\multicolumn{2}{|c|}{ Model }} & \multicolumn{2}{|c|}{ Unstandardized Coefficients } & \multirow{2}{*}{$\begin{array}{l}\text { Standardized Coefficients } \\
\text { Beta }\end{array}$} & \multirow{2}{*}{$\mathbf{t}$} & \multirow{2}{*}{ Sig. } \\
\hline & & B & Std. Error & & & \\
\hline \multirow{4}{*}{1} & (Constant) & 3.948 & 521 & & 7.578 & 000 \\
\hline & Bond market & 336 & 146 & 366 & 2.307 & 029 \\
\hline & Securitized products & 449 & 156 & 455 & 2.887 & 007 \\
\hline & Equity market investment & 275 & 157 & 278 & 1.752 & 091 \\
\hline
\end{tabular}

a. Dependent Variable: Profitability of BK Rwanda.

The Linear Regression Test between Capital Markets and profitability of BK Rwanda show the result of

$$
y=3.948+0.336 X_{1}+0.449 X_{2}+0.2750 . X_{3}+\varepsilon
$$

The $\mathrm{X}_{1}$ represent Bond market, $\mathrm{X}_{2}$ represent Securitized products, $\mathrm{X}_{3}$ is Equity market investment and lastly, represents standard errors. As explained by the linear regression equation, it is clear that one unit change of $\mathrm{X}_{1}, \mathrm{X}_{2}$, and $\mathrm{X}_{3}$ lead to change times $0.336,0.449$, and 0.275 of dependent variable respectively. In the other case if all independent variable indicators are zero, the dependent variable equals to the constant (3.948).

Thus, according to the results indicated to the table 5, there is positive relationship between profitability and Bond market; securitized products; and Equity market investment as indicators of capital markets.

a) When BK Rwanda adopts Bond market only without other factors, result on the profitability became

$$
y=3.948+0.336 X_{1}+.146
$$

b) While BK used Securitized products without the presence of bond market and equity market, the profitability result was

$$
y=3.948+0.449 X_{2}+.156
$$

c) Therefore, when BK used only Equity Market investment, the profitability was becoming

$$
y=3.948+0.275 X_{3}+.157
$$

\subsubsection{Capital Markets and Liquidity of Bank of Kigali Rwanda}

This section illustrates the influence of Capital Markets and liquidity of Bank of Kigali Rwanda as table 9 presented as follows.

Table 9. Linear Regression Test of Capital Markets factors on the Liquidity of Bank of Kigali Rwanda.

\begin{tabular}{lllll}
\hline \multirow{2}{*}{ Model } & \multicolumn{2}{l}{ Unstandardized Coefficients } & Standardized Coefficients & Sig. \\
\cline { 2 - 3 } & B & Std. Error & Beta & \\
\hline (Constant) & 1.170 & 658 & & 08 \\
Bond market & 203 & 083 & 028 & 2.434 \\
Securitized products & 148 & 076 & 024 & 1.778 \\
Equity market investment & 343 & 210 & 039 & 1.939 \\
\hline
\end{tabular}

a. Dependent Variable: Liquidity of BK Rwanda.

Linear Regression Test between Capital Markets factors and Liquidity of Bank of Kigali Rwanda shows the result of

$$
y=1.170+0.203 X_{1}+0.148 X_{2}+0.343 . X_{3}+\varepsilon
$$

The $\mathrm{X}_{1}$ represent Bond market, $\mathrm{X}_{2}$ represent Securitized products, $\mathrm{X}_{3}$ is Equity market investment and lastly, $\varepsilon$ represents standard errors. As explained by the linear regression equation, it is clear that one unit change of $\mathrm{X}_{1}, \mathrm{X}_{2}$, and $\mathrm{X}_{3}$ lead to change times $0.203,0.148$, and 0.343 of dependent variable respectively. In the other case if all independent variable indicators are zero, the dependent variable equals to the constant (1.170). Thus, according to the result indicated to the table 9, there is significant influence between liquidity and Bond market; securitized products; Equity market investment as indicators of Capital Markets of BK Rwanda.

Bond market of BK Rwanda influences the liquidity of BK Rwanda on 


$$
y=1.170+0.203 X_{1}+.083
$$

Securitized products of BK Rwanda influence the liquidity on

$$
y=1.170+0.148 X_{2}+.076
$$

When BK used only Equity Market investment, the liquidity was

$$
y=1.170+0.343 . X_{3}+.210
$$

\subsubsection{Capital Markets and Capital Adequacy of Bank of Kigali Rwanda}

This section illustrates the information about the relationship between Capital Markets and Capital adequacy of Bank of Kigali Rwanda.

Table 10. Linear Regression Test of Capital Markets factors on Capital adequacy of Bank of Kigali Rwanda.

\begin{tabular}{llllll}
\hline \multirow{2}{*}{ Model } & \multicolumn{2}{l}{ Unstandardized Coefficients } & Standardized Coefficients & \multirow{2}{*}{ Sig. } \\
\cline { 3 - 5 } & B & 1.028 & Std. Error & Beta & 016 \\
\hline \multirow{2}{*}{1} & (Constant) & 106 & 394 & & 2.609 \\
& Bond market & 131 & 182 & 244 & 585 \\
& Securitized products & 061 & 295 & 2.144 \\
& Equity market investment & -.021 & 161 & -.036 & -.129 \\
\hline
\end{tabular}

a. Dependent Variable: Capital adequacy of Bank of Kigali Rwanda.

Linear Regression Test of Capital Markets factors on Capital adequacy of Bank of Kigali Rwanda shows the result of

$$
y=1.028+0.106 X_{1}+0.131 X_{2}-0.021 X_{3}+\varepsilon
$$

The $\mathrm{X}_{1}$ represent Bond market, $\mathrm{X}_{2}$ represent Securitized products, $\mathrm{X}_{3}$ is Equity market investment and lastly, $\varepsilon$ represents standard errors. As explained by the linear regression equation, it is clear that one unit change of $\mathrm{X}_{1}, \mathrm{X}_{2}$, and $\mathrm{X}_{3}$ lead to change times 0.106, 0.131, and - 0.021 of dependent variable respectively. In the other case if all independent variable indicators are zero, the dependent variable equals to the constant (1.028). Thus, according to the result indicated in table 10, there is significant influence between capital adequacy and Bond market; securitized products as indicators of Capital Markets of BK Rwanda. Bond market of BK.

Rwanda influences capital adequacy of BK Rwanda on

$$
y=1.028+0.106 X_{1}+.182
$$

Securitized products of BK Rwanda influence the liquidity on

$$
y=1.028+0.131 X_{2}+.061
$$

When BK used only Equity Market investment, the liquidity was

$$
y=1.028-0.021 X_{3}+.161
$$

\subsection{Financial Performance of Bank of Kigali Rwanda After Joining Capita Markets}

The profitability ratio is considered as one measure of financial performance of commercial bank like Bank of Kigali. However, the common profitability ratios used in analyzing of BK financial performance include GPM Ratio, Net Profit Margin Ratio (NPM), Return on Assets (ROA), Return on Equity (ROE).

Table 11. Gross Profit Margin (GPM) Ratio of Bank of Kigali.

\begin{tabular}{llllll}
\hline & $\mathbf{2 0 1 2}$ & $\mathbf{2 0 1 3}$ & $\mathbf{2 0 1 4}$ & $\mathbf{2 0 1 5}$ & \multicolumn{2}{c}{$\mathbf{2 0 1 6}$} \\
\cline { 2 - 6 } & "Rwf '000" & "Rwf '000” & "Rwf '000” & "Rwf '000 & "Rwf '000” \\
\hline Gross Profit (GP) & 14466909 & 18756236 & 22758705 & $25,737,232$ & $29,981,115$ \\
Net Sales (NS) & $34,758,424$ & $44,759,241$ & $50,637,578$ & $56,170,282$ & 34172034 \\
GPM: GP/NS*100 & $41.62 \%$ & $41.90 \%$ & $44.94 \%$ & $45.82 \%$ & $59,823,515$ \\
\hline
\end{tabular}

Source: Secondary data, BK annual reports, (2017).

The GPM indicates the percentages of sales available for expenses and profit after the cost of merchandise is deducted from sales. Table 11 above illustrates the profitability evolution of BK in 2012 was $41.62 \%$ increased clearly in
2013 until 41.90\% and in 2014, Gross profit Margin was $44.94 \%$. The year 2015 , GPM was $45.82 \%$; 2016 GPM was $50.12 \%$ and 2017 , it was $45.80 \%$.

Table 12. Net profit ratios of Bank of Kigali.

\begin{tabular}{lllllll}
\hline & $\mathbf{2 0 1 2}$ “Rwf '000” & $\mathbf{2 0 1 3}$ “Rwf '000” & $\mathbf{2 0 1 4}$ “Rwf '000” & $\mathbf{2 0 1 5}$ “Rwf '000” & $\mathbf{2 0 1 6}$ “Rwf '000” & $\mathbf{2 0 1 7}$ “Rwf '000 \\
\hline Net profit & $11,781,336$ & $14,830,235$ & $18,316,825$ & $20,484,058$ & 20755867 \\
Net sales & $34,758,424$ & $44,759,241$ & $50,637,587$ & $56,170,282$ & 59823515 \\
NPM NP/NS*100 & $33.89 \%$ & $33.13 \%$ & $36.17 \%$ & $36.46 \%$ & 348880 \\
\hline
\end{tabular}

Source: Secondary data, BK annual reports, (2017)

The Profit margin (after tax) tells you the profit per sales after all expenses are deducted from sales. The table 12 presents the net profit ratio in 2012 which is $33.89 \% \%$; in 2013 net profit increased on $33.13 \% \%$; in 2014 , NP was 
$36.17 \%$; in 2015, NP was 36.46\%.2016, NPM was $34.46 \%$; $\quad$ and in 2017 , NPM was $31.29 \%$.

Table 13. Return on Equity of Bank of Kigali.

\begin{tabular}{|c|c|c|c|c|c|c|}
\hline & $\begin{array}{l}2012 \\
\text { "Rwf '000" }\end{array}$ & $\begin{array}{l}2013 \\
\text { "Rwf '000" }\end{array}$ & $\begin{array}{l}2014 \\
\text { "Rwf '000" }\end{array}$ & $\begin{array}{l}2015 \\
\text { "Rwf '000" }\end{array}$ & $\begin{array}{l}2016 \\
\text { "Rwf '000" }\end{array}$ & $\begin{array}{l}2017 \\
\text { "Rwf '000 }\end{array}$ \\
\hline Net income & $11,781,336$ & $14,830,235$ & $18,316,825$ & $20,484,058$ & 20755867 & 23348880 \\
\hline Shareholder Investment & $63,107,293$ & $70,763,684$ & $89,547,734$ & $99,245,545$ & 108485600 & 122750132 \\
\hline $\mathrm{ROE}=\mathrm{NI} / \mathrm{SI} * 100$ & $18.66 \%$ & $20.95 \%$ & $20.45 \%$ & $20.63 \%$ & $19.13 \%$ & $19.02 \%$ \\
\hline
\end{tabular}

Source: Secondary data, BK annual reports, (2017)

Returned stockholders 'equity (after tax) reveals the percentage of profit after income taxes that the corporation earned on its average common stockholders 'balances preferred stock, or the earnings per shares (EPS): Expresses the corporation's net income after tax on a per share of common stock basis. EPS $=$ Net income after tax/weighted average number of common shares outstanding. The table 13 shows that ROE was in 2012 became $18.66 \%$, while in 2013 was became $20.95 \%$ and in 2014 became $20.45 \%$, and in 2015 , ROE was $20.63 \%$. In 2016 , ROE was $19.13 \%$, and 2017 it became $19.02 \%$.

Table 14. Return on Assets of Bank of Kigali.

\begin{tabular}{|c|c|c|c|c|c|c|}
\hline & $\begin{array}{l}2012 \\
\text { "Rwf '000" }\end{array}$ & $\begin{array}{l}2013 \\
\text { "Rwf '000" }\end{array}$ & $\begin{array}{l}2014 \\
\text { "Rwf '000" }\end{array}$ & $\begin{array}{l}2015 \\
\text { "Rwf '000" }\end{array}$ & $\begin{array}{l}2016 \\
\text { "Rwf '000" }\end{array}$ & $\begin{array}{l}2017 \\
\text { "Rwf '000 }\end{array}$ \\
\hline Net income & $11,781,336$ & $14,830,235$ & $18,316,825$ & $20,484,058$ & 20755867 & 23348880 \\
\hline Assets & $322,794,214$ & $422,360,073$ & $422,360,964$ & $561,226,400$ & $638,336,598$ & $727,204,700$ \\
\hline $\mathrm{ROA}=\left(\mathrm{NI} / \mathrm{A}^{*} 100\right)$ & $3.64 \%$ & $3.51 \%$ & $3.79 \%$ & $3.64 \%$ & $3.25 \%$ & $3.21 \%$ \\
\hline
\end{tabular}

Source: Secondary data, BK Annual reports, (2017)

The table 14 presents return on Asset was in 2012 was 3.64\%, in 2013; return on asset was 3.51\%, in 2014, ROA was 3.79\% while the year of 2015, ROA was $3.64 \%$ and in 2016 , ROA was $4.10 \%$. In 2016, ROA was $3.25 \%$ while in 2017 , ROA was $3.21 \%$.

Table 15. Current Ratio of Bank of Kigali.

\begin{tabular}{|c|c|c|c|c|c|c|}
\hline & $\begin{array}{l}2012 \\
\text { "Rwf '000" }\end{array}$ & $\begin{array}{l}2013 \\
\text { "Rwf '000" }\end{array}$ & $\begin{array}{l}2014 \\
\text { "Rwf '000" }\end{array}$ & $\begin{array}{l}2015 \\
\text { "Rwf '000" }\end{array}$ & $\begin{array}{l}2016 \\
\text { "Rwf '000" }\end{array}$ & $\begin{array}{l}2017 \\
\text { "Rwf '000 }\end{array}$ \\
\hline Current assets & $54,304,202$ & $199,023,241$ & $233,439,509$ & $313,925,535$ & 385824570 & 471704315 \\
\hline Current liabilities & $5,894,345$ & $8,705,581$ & $10,860,278$ & $9,656,897$ & 6286996 & 17390729 \\
\hline $\mathrm{CR}=(\mathrm{CA} / \mathrm{CL})$ & 9.21 & 22.86 & 21.49 & 32.50 & 6136,87 & 2712.38 \\
\hline
\end{tabular}

Source: Secondary data, BK annual reports, (2017)

The current ratio measures the liquidity of the company. It provides the investor with a measure of the company's ability to pay current liabilities with current assets. The calculation of the measure is current ratio equals current assets / current liabilities. The table 12 presents the current ratio of $\mathrm{BK}$ where current ratio was 9.21 in 2012; CR was 22.86in 2013; and in 2014, CR was 21.49, and in 2015, CR was 32.50 ; in 2016, CR was 6136.87 and 2017, CR was 2712.38.

\section{Conclusion}

According to the findings, the problem of the study was solved, research objectives were achieved, research questions were answered and hypotheses were verified, the null hypothesis that said "there is no significant relationship between Capital Markets and financial performance of bank of Kigali (BK) " was rejected after data analysis, while alternative hypothesis that said "there is significant relationship between Capital Markets and financial performance of bank of Kigali (BK) "was retained. The findings help us to confirm that there is a there is a significant relation between Capital Markets and financial performance of Bank of Kigali in Rwanda.

\section{Recommendation}

The bank of Rwanda management should work much harder to improve its corporate governance, respond positively to economic conditions, and wake up to constructive risk management. This improves the corporate image of the commercial banks thereby raising the prices of the shares. When more people buy the shares, the banks raise more capital hence improved performance [1].

The management of the banks should work on proper advertising of their bond markets by attaching attractive interest rates [8]. This entices the dealers to take more debt in form of loans, thus making the banks more liquid in the long run [3].

The securitized products like loans should be offered to the public after a clear assessment on who legally qualifies for the product [5]. This puts the risk of default very low. When this happens, the bank raises more liquid hence improved performance. 


\section{References}

[1] Aghion, P., Bacchetta, P. \& Banerjee, A. (2004), Financial Development and the Instability Of Open Economies, National Bureau of Economic Research, Working Paper No. 10246.

[2] Arestis, P., Demetriades, P. O. \& Luintel, K. B. (2001), Financial development and Economic Growth: The Role of Stock Markets', Journal of Money, Credit and Banking, February, Vol. 33, No.

[3] Baronov, D. (2004), Conceptual foundations of social research methods, Paradigm Publishers, Boulder.

[4] Beck, T. \& Levine, R. (2017), 'Stock markets, Banks and Growth: Correlation or causality', The World Bank, Policy Research Paper No. 2670.

[5] Beck, T. (2006), 'Creating an efficient financial system: Challenges in a global economy', World Bank, Working Paper No. 3856.

[6] Choi, S., Smith, B. \& Boyd, J. (1996), 'Inflation, financial markets, and capital formation', The Federal Reserve Bank of St. Louis Review, Vol. May/.

[7] Claessens, S., Klingebiel, D. \& Schmukler, S. L. (2016), 'Explaining the migration of stocks from exchanges in emerging economies to international centers', The World Bank, Policy Research Working Paper No. 2816.58 (66).
[8] Damodaran, A. (2001), corporate finance: Theory and practice, 2nd ed, John Wiley \& Sons Inc., New York. Development', Journal of Development Economics, vol. 66 (2 Dec), pp. 465-504. FEAS (2006), 'Market Capitalisation \& Index', Federation of Euro-Asian Stock Exchanges, Found at: http://www.feas.org/Member.cfm?MemberID=10.

[9] Levine, R. \& Zervos, S. (1996). Stock market development and long-run growth. The World Bank Economic Review, Volume 10, Issue 2.

[10] Levine, R. and Zervos S. (1998), 'Stock Markets, Banks, and Economic Growth', American Economic Review 88, p. 537558.

[11] McKinnon, R. I. (1973). Money and capital in economic development. The Brookings Institution, 1775 Massachusetts Avenue, N. W., Washington D. C. Retrieved March 2011.

[12] McKinnon, R. I. (1973), Money and Capital in Economic Development, Brooking Institution, Washington, DC, Microfinance Bill, 2006.

[13] Uth off, A. (2000), 'Pension reform in Chile', in Sawyers, L., Schydlowsky, D. \& Nickerson, D. (eds), Emerging financial markets in the global economy, American University, Washington DC.

[14] World Bank (1989). Financial systems and development. World Development Report, World Bank and Oxford University Press, pg 26, Washington DC. Washington DC. 